\section{Pacific Northwest}

National Laboratory

Operated by Battelle for the

U.S. Department of Energy

\title{
Mica-Based Composite Compressive Seals for SOFC
}

\author{
Y.S. Chou \\ K.D. Meinhardt \\ J.W. Stevenson \\ P. Singh
}

July 2004

Prepared for the U.S. Department of Energy

under Contract DE-AC06-76RL01830 


\title{
DISCLAIMER
}

This report was prepared as an account of work sponsored by an agency of the United States Government. Neither the United States Government nor any agency thereof, nor Battelle Memorial Institute, nor any of their employees, makes any warranty, express or implied, or assumes any legal liability or responsibility for the accuracy, completeness, or usefulness of any information, apparatus, product, or process disclosed, or represents that its use would not infringe privately owned rights. Reference herein to any specific commercial product, process, or service by trade name, trademark, manufacturer, or otherwise does not necessarily constitute or imply its endorsement, recommendation, or favoring by the United States Government or any agency thereof, or Battelle Memorial Institute. The views and opinions of authors expressed herein do not necessarily state or reflect those of the United States Government or any agency thereof.

\author{
PACIFIC NORTHWEST NATIONAL LABORATORY \\ operated by \\ BATTELLE \\ for the \\ UNITED STATES DEPARTMENT OF ENERGY \\ under Contract DE-AC05-76RL01830
}

Printed in the United States of America
Available to DOE and DOE contractors from the Office of Scientific and Technical Information,
P.O. Box 62, Oak Ridge, TN 37831-0062;
ph: (865) 576-8401
fax: $(865)$ 576-5728
email: reports@adonis.osti.gov

\begin{abstract}
Available to the public from the National Technical Information Service, U.S. Department of Commerce, 5285 Port Royal Rd., Springfield, VA 22161 ph: (800) 553-6847 fax: $(703) 605-6900$ email: orders@ntis.fedworld.gov online ordering: http://www.ntis.gov/ordering.htm
\end{abstract}

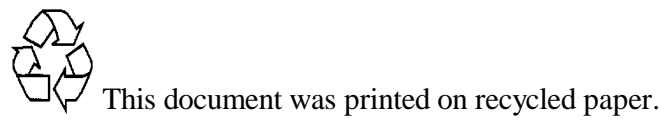




\title{
Mica-based Composite Compressive Seals for SOFC
}

\author{
Yeong-shyung matt Chou, Kerry Meinhardt, Jeff Stevenson, and Prabhakar Singh, Pacific Northwest
}

National Laboratory

\section{Introduction}

Pacific Northwest National Laboratory is developing glass - mica "hybrid" composite compressive seals for high temperature applications such as solid oxide fuel cell stacks. The seals are easy to fabricate, and offer stable, low leak rates.

\section{Technology}

One of the critical challenges facing planar solid oxide fuel cell (SOFC) developers is the need for reliable sealing technology. Seals are required which will offer long-term stability in the high temperature SOFC environment and also maintain their integrity during thermal cycling. Several different approaches for sealing SOFC stacks are under development, including glass or glassceramic seals, metallic brazes, and compressive seals. Compressive seals potentially offer a significant and unique advantage over the other approaches by providing a means of mechanically "decoupling" adjacent stack components, thereby minimizing the need for closely matching the coefficients of thermal expansion (CTE) of the various SOFC stack components. In an attempt to help the SOFC industry overcome sealing challenges, PNNL is developing mica-based hybrid compressive seals which exhibit leak rates 2 to 3 orders of magnitude lower than obtained with simple mica gasket seals.

\section{Materials and Fabrication}

The hybrid seals consist of commercially available Phlogopite mica paper sandwiched between layers of a proprietary SOFC glassceramic seal material (US

Patents 6,430,966; 6,532,769). The seals are fabricated by inserting the mica paper between polymer tapes (prepared by conventional tape casting techniques) which contain the glass-ceramic powder. Sealing is accomplished by placing the tape/mica/tape structure between the stack components to be sealed, followed by heat treatment (typically to $830^{\circ} \mathrm{C}$ ) to soften the glass sufficiently to cause bonding to the component surfaces. Final seal thickness is typically $\sim 100-200 \mu \mathrm{m}$. (Figure 1)

\section{Testing Procedures}

For leak rate tests, the seals were placed between an Inconel600 pipe and an alumina substrate. A compressive load was applied

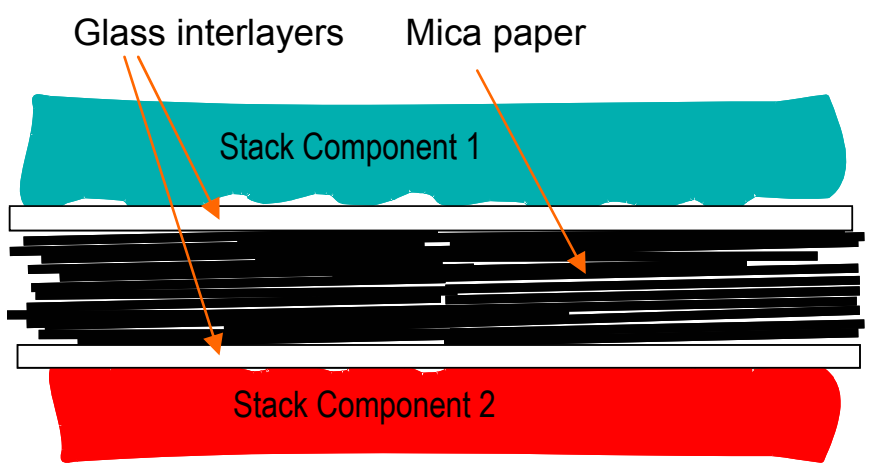

Figure 1. Schematic illustration of hybrid mica seal. Mica paper is in center of seal (black) with glass layers (white) on each side to fill mica/stack component interfaces.

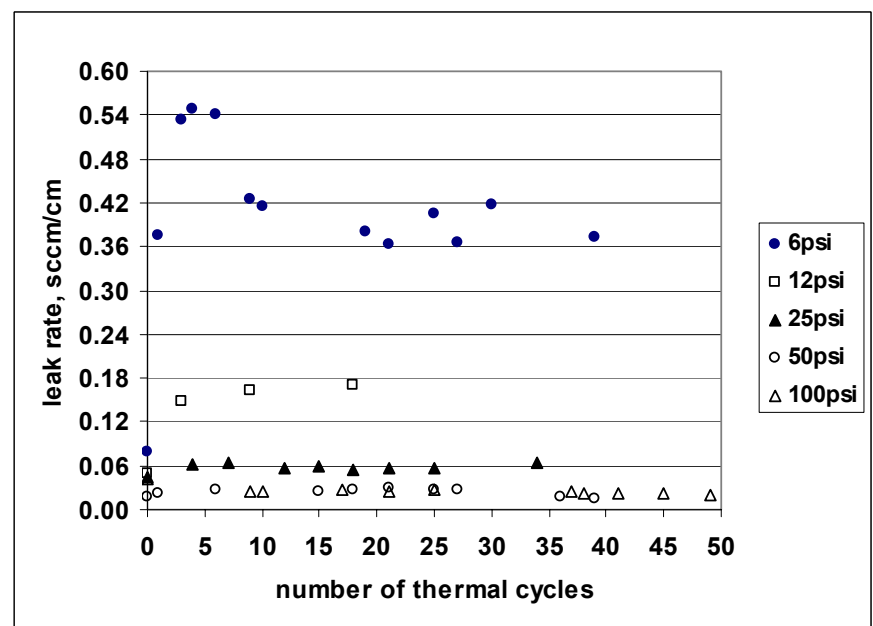

Figure 2. Leak rates at $800^{\circ} \mathrm{C}$ of a 2" x 2" hybrid Phlogopite mica seal pressed under various compressive loads.

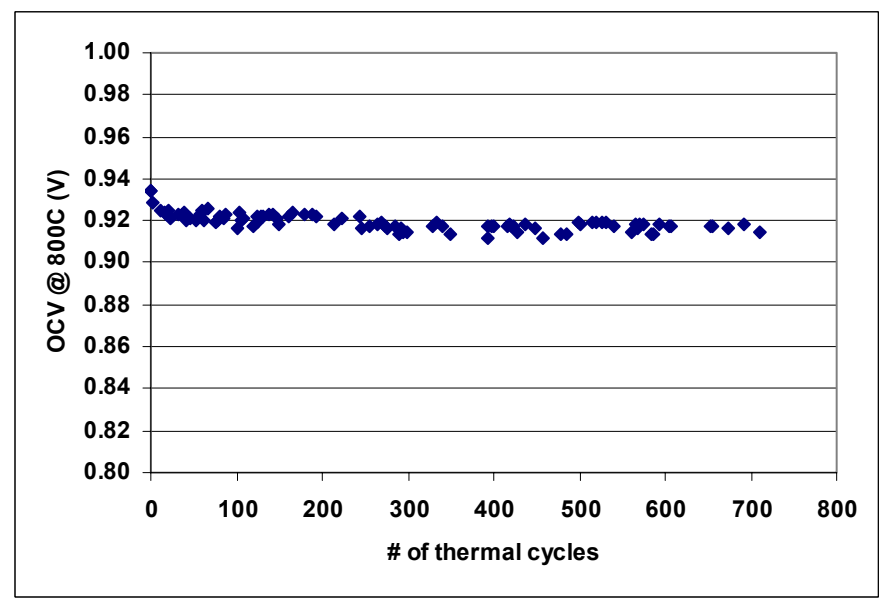

Figure 3. OCV results for thermal cycle tests on 2"x 2" 8YSZ plate with hybrid Phlogopite mica seal compressed at 100 psi. 
throughout the tests, including the heating and cooling cycles. The leak rates were determined with high-purity helium using a 2 psi differential. Thermal cycling was conducted between $100^{\circ} \mathrm{C}$ and $800^{\circ} \mathrm{C}$, with 2 hour dwells at $800^{\circ} \mathrm{C}$. Open circuit voltage (OCV) tests were also conducted, using electroded dense 8YSZ plates pressed between an Inconel cap and an alumina base support; in these tests the mica seals were located between the 8YSZ and the Inconel fixture.

\section{Performance}

Results for thermal cyclic leak rate testing of a 2"x 2" hybrid seal (1 layer of mica paper sandwiched between 2 layers of glassceramic) are shown in Figure 2. When compressed at $\sim 25$ psi or more, the seals exhibited low leak rates and excellent stability during repeated thermal cycling. It is important to emphasize that, in this test, the materials adjacent to the seal had a significant CTE mismatch (Inconel600, with a CTE of $\sim 16-17 \mathrm{ppm} / \mathrm{K}$ vs. alumina, with a CTE of $\sim 8 \mathrm{ppm} / \mathrm{K}$ ). As a point of comparison, similar tests using a glass-ceramic seal alone between these materials resulted in seal failure after a single thermal cycle.

Results for OCV testing of a 2"x 2" seal compressed at 100 psi are shown in Figure 3. The OCV measurements were conducted using a dilute moist hydrogen "fuel" (2.55$2.72 \% \mathrm{H}_{2}$ / balance $\mathrm{Ar}$ ) / $3 \% \mathrm{H}_{2} \mathrm{O}$ ) vs. air, for which the calculated Nernst voltage at $800^{\circ} \mathrm{C}$ is $0.932-0.934 \mathrm{~V}$. Over 800 thermal cycles (heated from $100^{\circ} \mathrm{C}$ to $800^{\circ} \mathrm{C}$ in 30 minutes), the OCV decreased by only $2 \%$.

Testing was also performed using lower applied compressive stresses. Figure 4 shows OCV as a function of thermal cycles and fuel flow rate for a 3.5"x 3.5" seal compressed at only $12.5 \mathrm{psi}$. These OCV measurements were conducted using moist pure hydrogen $\left(97 \% \mathrm{H}_{2} / 3 \% \mathrm{H}_{2} \mathrm{O}\right)$ vs. air, for which the calculated Nernst voltage is $1.10 \mathrm{~V}$ at $800^{\circ} \mathrm{C}$. As an approximate reference point to help interpret the flow rate results, one can assume that the 3.5 " $\times 3.5$ " footprint would correspond to a cell with an active area of $\sim 55 \mathrm{~cm}^{2}$. Assuming a current density of $0.7 \mathrm{~A} / \mathrm{cm}^{2}$ and $80 \%$ fuel utilization, a fuel flow rate of $\sim 270 \mathrm{sccm}$ would be required; for flow rates in that range, the measured OCV was essentially identical to the calculated Nernst voltage.

Note that the leak rates shown (Fig. 2) were measured at 2 psid; reduction of

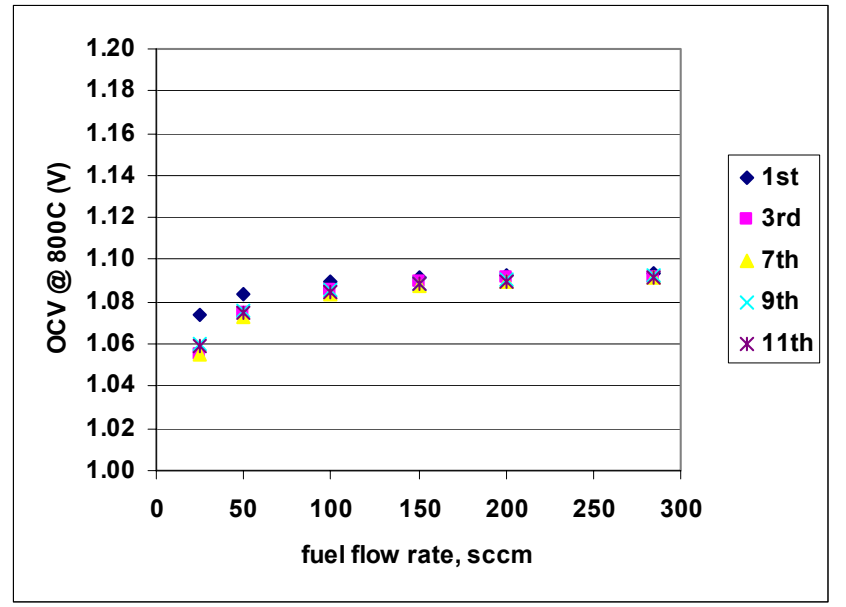

Figure 4. OCV of 3.5"x 3.5" hybrid Phlogopite mica seal as a function of fuel flow rate and thermal cycles, using reduced applied compressive stress (12.5 psi).

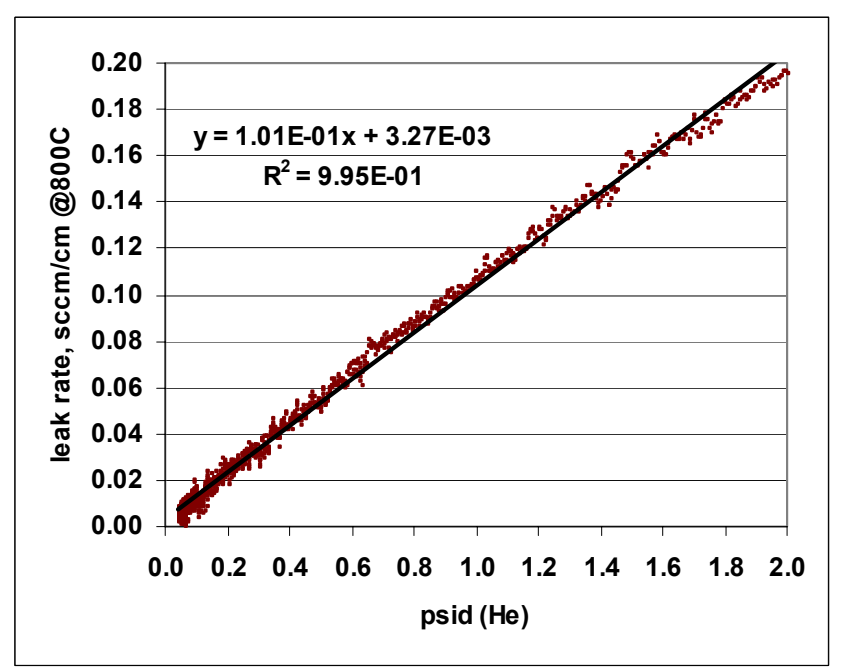

Figure 5. Effect of differential pressure on the leak rate of a 2"x2" hybrid Phlogopite mica seal pressed at 12.5 psi. Measurement was taken after 19 thermal cycles.

the pressure drop across the seal resulted in a linear decrease in leak rate. A typical example is shown in Figure 5 for a 2"x 2" hybrid Phlogopite mica pressed at 12.5 psi; the data in Figure 5 were taken after 19 thermal cycles. For pressure drops of 0.1-0.2 psid, the seal leak rate was $\sim 0.02 \mathrm{sccm} / \mathrm{cm}$.

\section{Contacts}

For more information or to request samples, please contact: Jeff Stevenson, jeff.stevenson@pnl.gov, 509-372-4697

Prabhakar Singh, Prabhakar.Singh@pnl.gov; 509-375-5945

\section{Acknowledgements}

The work described in this report was funded through the Solid-State Energy Conversion Alliance (SECA) Core Technology Program by the US Department of Energy's National Energy Technology Laboratory (NETL). Pacific Northwest National Laboratory is operated by Battelle Memorial Institute for the US Department of Energy under Contract no. DE-AC06-76RLO 1830. 